\title{
Increased Incidence of Acute Ischemic Stroke in COVID-19 Patients
}

\author{
Ahmet Nedim Kahraman ${ }^{1}$ (iD , Ahmet Vural' ${ }^{1}$ (D
}

${ }^{1}$ Department of Radiology, University of Health Science Fatih Sultan Mehmet Training and Research Hospital, Istanbul, Turkey

\section{Ahmet Nedim KAHRAMAN}

Ahmet VURAL

\author{
Correspondence: Ahmet Vural \\ Department of Radiology, University of Health \\ Science Fatih Sultan Mehmet Training and \\ Research Hospital, Istanbul, Turkey \\ Phone: +905327277461 \\ E-mail: vuralahmet@gmail.com
}

\begin{abstract}
Purpose: The coronavirus disease 2019 (COVID-19) is an active epidemic that is rapidly spreading globally with various complications. Although there are publications on the frequency of thromboembolic complications with COVID-19, the number of publications showing a strong relationship with acute ischemic stroke is few. We aimed to evaluate the link between COVID-19 and acute ischemic stroke.

Methods: One hundred and six patient were screened retrospectively who were underwent brain diffusion MRI with the suspicion of acute stroke in our institution between April and August 2020 when the COVID-19 pandemic intense. The data on diagnosis of COVID-19 infection were analyzed according to patient demographics and risk factors; patients are separated into two groups as with and without acute ischemic stroke findings. A univariate analysis was performed to show the relationship of risk factors and the presence of COVID-19 with acute ischemic stroke.
\end{abstract}

Results: Acute stroke imaging findings were detected in 39 of 106 patients; and 67 patients without signs of acute ischemic stroke were considered as the control group. The mean age for subjects and controls was $61.8 \pm 4.8$ and $61.2 \pm 4.9$ years, respectively. Seventeen (43.6\%) of the patients with acute ischemic stroke findings had COVID-19 infection. In the control group, 12 (17.9\%) were positive for COVID-19 $(p<0.05)$. No significant relationship was found for age, gender and other risk factors. However, COVID-19 infection had a significant independent association with acute ischemic stroke compared to control subjects ( $0 \mathrm{R} 3.5 ; 95 \% \mathrm{Cl} 1.4-8.6 ; \mathrm{P}<0.005)$.

Conclusion: COVID-19 infection poses an increased risk for acute ischemic stroke, and therefore, it is necessary to be careful in terms of acute ischemic stroke in patients followed up for COVID-19, and imaging with diffusion MRI in suspected cases.

Keywords: COVID-19, Ischemic Stroke, Magnetic Resonance Imaging, Diffusion Weighted Imaging

\section{COVID-19 Hastalarında Akut İskemik İnme Sıklığında Artış}

ÖZET

Amaç: Koronavirüs hastalığı 2019 (COVID-19), çeşitli komplikasyonları olan küresel olarak hızla yayılan aktif bir salgındır. COVID-19 ile tromboembolik komplikasyonların sıklığına yönelik yayınlar bulunmakla birlikte akut iskemik inme ile güçlü bir ilişki gösterilen yayın sayııı azdır. Bu çalışmada COVID-19 ile akut iskemik inme arasındaki bağı değerlendirmek amaçlanmıştır.

Metodlar: COVID-19 pandemisinin yoğun olduğu Nisan - Ağustos 2020 döneminde kurumumuzda akut iskemik inme şüphesi ile beyin difüzyon MRI yapılan hastalar retrospektif olarak tarandı. Yaş ve risk faktörleri göz önünde bulundurularak belirlenmiş, 106 hasta çalışmaya dahil edildi. Difüzyon MRI bulgularına göre hastalar akut iskemik inme bulguları olan ve olmayan iki grup olarak belirlendi. Tüm hastalar için COVID-19 enfeksiyonu tanısı, hasta demografisi ve risk faktörleri ile ilgili veriler toplandı. Risk faktörlerinin ve COVID-19 varlığının, akut iskemik inme ile ilişkisini gösterebilmek amacı ile tek değişkenli bir analiz yapııdı.

Bulgular: Çalışmaya dahil edilen 106 hastanın 39'unda akut inme görüntüleme bulguları mevcuttu. Akut iskemik inme bulgusu saptanmayan 67 hasta kontrol grubu olarak değerlendirildi. Olgular ve kontroller için ortalama yaş sırasııla $61.8 \pm 4.8$ ve $61.2 \pm 4.9$ yıldı. Akut iskemik inme bulgularına sahip hastaların 17'sinde (\%43.6) COVID-19 enfeksiyonu vardı. Kontrol grubunun ise 12'sinde (\%17.9) COVID-19 pozitif idi $(P<0.05)$. Yaş, cinsiyet ve diğer risk faktörleri için anlamlı bir ilişki saptanmadı. Ancak COVID-19 enfeksiyonu, kontrol deneklerine kıyasla akut iskemik inme ile anlamlı bağımsız bir ilişkiye sahipti (OR 3,5; \% $95 \mathrm{Cl} 1,4-8.6 ; \mathrm{P}<0.005)$.

Sonuç: COVID-19 enfeksiyonunun, akut iskemik inme için artmış risk oluşturduğu ve bu nedenle COVID-19 nedeniyle takip edilen hastalarda akut iskemik inme yönünden dikkatli olunması ve şüpheli durumlarda difüzyon MRI ile görüntülemenin gerektiği görülmektedir.

Anahtar Kelimeler: COVID-19, İskemik İnme, Manyetik Rezonans Görüntüleme, Difüzyon Ağırlıklı Görüntüleme

\footnotetext{
Received : 17 September 2021

Accepted : 140 ctober 2021
} 
n December 2019, a new Severe Acute Respiratory Syndrome coronavirus-2 (SARS-CoV-2) disease emerged in Wuhan, China (1). Coronavirus disease 2019 (COVID-19), the clinical manifestation of SARS-CoV-2 infection, has led to a worldwide pandemic characterized by viral pneumonia and its complications. A significant number of patients experienced fever, cough, abdominal pain and diarrhea. According to the World Health Organization (WHO), over 169 million confirmed cases of COVID-19 have been identified worldwide as of May 2021, and at least 3.5 million patients have died from COVID-19 pneumonia and its complications (2).

With the identification of the disease, it was reported that the transmission was by respiratory droplets; and initially fever, shortness of breath and cough were the first symptoms. In the following period, symptoms such as gastrointestinal disease, headache, anosmia and confusion have been described $(3,4)$. Prior to COVID-19, it was known that respiratory tract infections increased the risk of short-term ischemic stroke (5-10). In reports from China, it is notified that neurological symptoms are seen in approximately one-third of patients hospitalized with COVID-19 (10). It has been reported that chronic diseases such as hypertension, coronary artery disease and diabetes mellitus adversely affect the prognosis of COVID-19 infection (11). It has been reported that SARS-CoV-2 virus, which causes COVID-19 infection, attaches to cells via the angiotensin converting enzyme (ACE) 2 receptors, which are mostly found in lung alveolar epithelial cells, small intestinal enterocytes and vascular endothelium (12). It has been suggested that the virus that binds to the cell wall may cause a cytokine storm, leading to an increased incidence of vascular thrombosis in patients $(13,14)$. There is increasing evidence that thrombosis is the leading cause of multi-organ failure including respiratory system (15). A number of studies have shown that coagulation disorders related to COVID-19 are associated with increased morbidity and mortality $(16,17)$.

Although an increased thromboembolic risk has been identified with COVID-19, the number of studies evaluating the incidence of acute ischemic stroke associated with COVID-19 seems to be limited (18). Our institution is one of the stroke centers of the Anatolian part of Istanbul province, and an increased incidence of acute ischemic stroke in COVID-19 patients compared to the normal population was noted as of April 2020, when the COVID-19 pandemic intensified. Therefore, the study was planned to determine whether there is a relationship between COVID-19 infection and the risk of acute ischemic stroke, and any possible risk factors.

\section{MATERIAL and METHODS}

The study was conducted as a retrospective case-control study in one of the few hospitals operating as a stroke center in the city of Istanbul, which has a large population. This retrospective study was approved by the scientific research commission established by the Ministry of Health of the Republic of Turkey for COVID-19 research. The study protocol was made in accordance with the Declaration of Helsinki and was approved by the ethics committee of Haydarpasa Numune TRH (HNEAH-KAEK-KK/182). During the period of April-August 2020, when the COVID-19 pandemic was intense, patients who underwent brain diffusion MRI with the suspicion of acute stroke in our institution were scanned retrospectively. In order to limit the risk factor created by age, 123 patients between the ages of 40-70 were included in the study. As the inclusion criteria of the patients in the study; The conditions were required to have clinical findings suggestive of acute ischemic stroke, to have had diffusion cranial MR imaging obtained with this suspicion, and to have Reverse-Transcriptase Polymerase Chain Reaction (RT-PCR) test results for SARSCoV-2. COVID-19 infection was confirmed by in vitro reverse transcriptase polymerase chain reaction (RT-PCR) with patient's nasopharyngeal swabs. If the RT-PCR test findings were negative, the patients were considered negative for COVID-19. Patients with a history of bleeding, tumor, and vasculitis were excluded from the study ( $\mathrm{n}=$ 6). Patients without clinical data $(n=8)$, poor quality or suspicious imaging findings $(n=3)$ were not included in the study. Thus, a total of 106 patients were obtained (Figure 1). According to diffusion MRI findings, patients were divided into two groups with and without acute stroke imaging findings. The patients were evaluated for the presence of diffusion-limiting focus consistent with acute ischemic stroke on MR imaging by two radiologists with 16 and 18 years of experience (Figure 2 and Figure 3). 


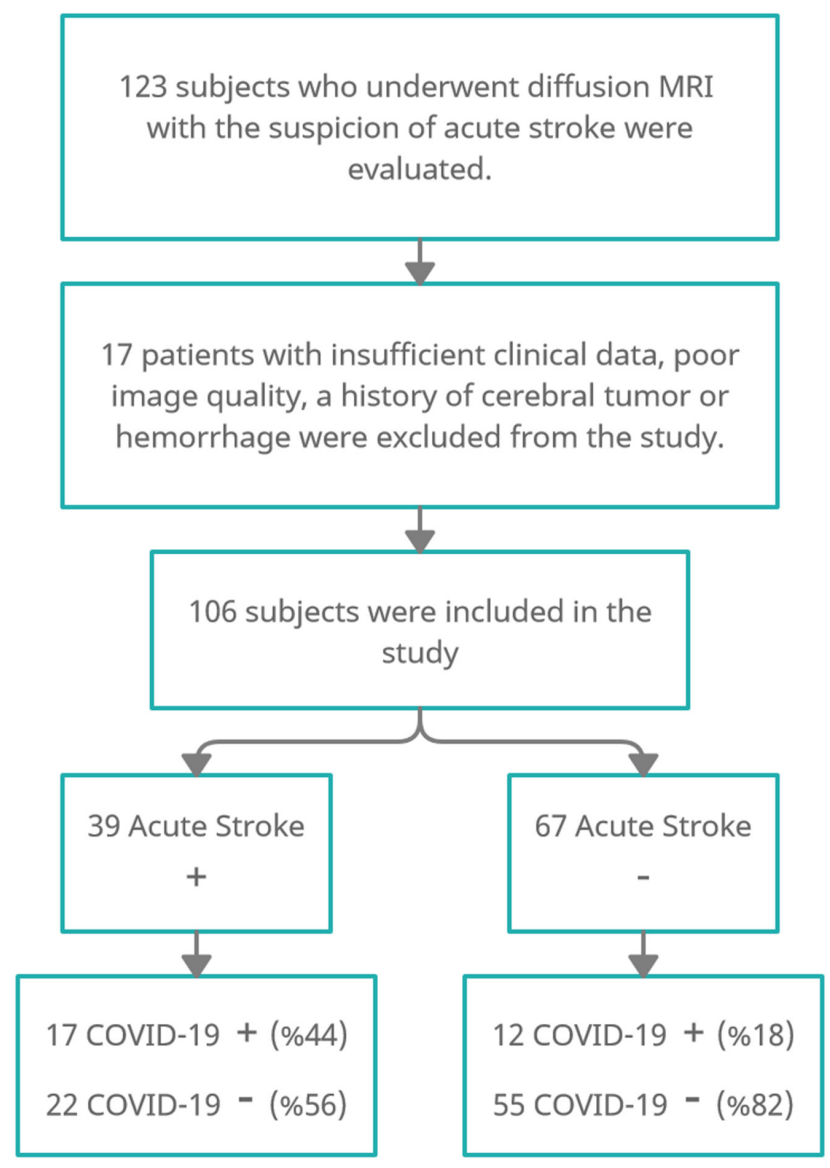

Figure 1 Flow chart of the study

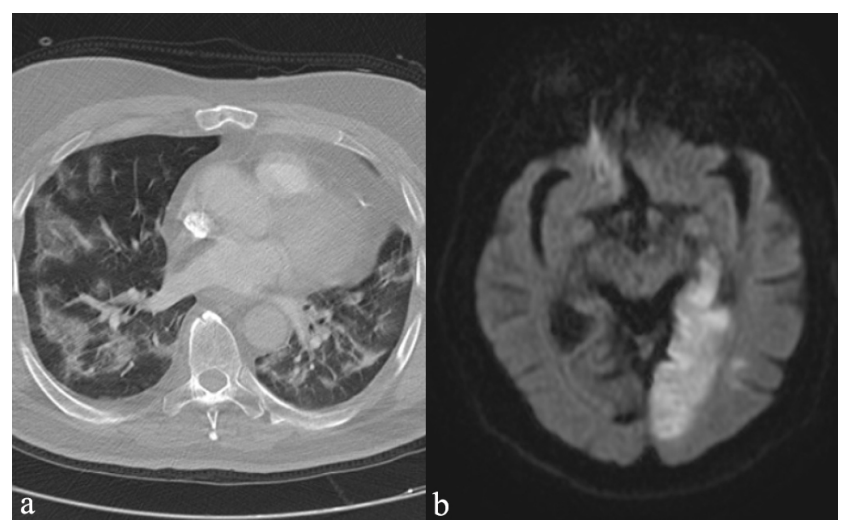

Figure 2 MR images of diffuse COVID-19 pneumonia in both lungs (a) and diffusion restriction showing left temporooccipital acute ischemic stroke in the same patient

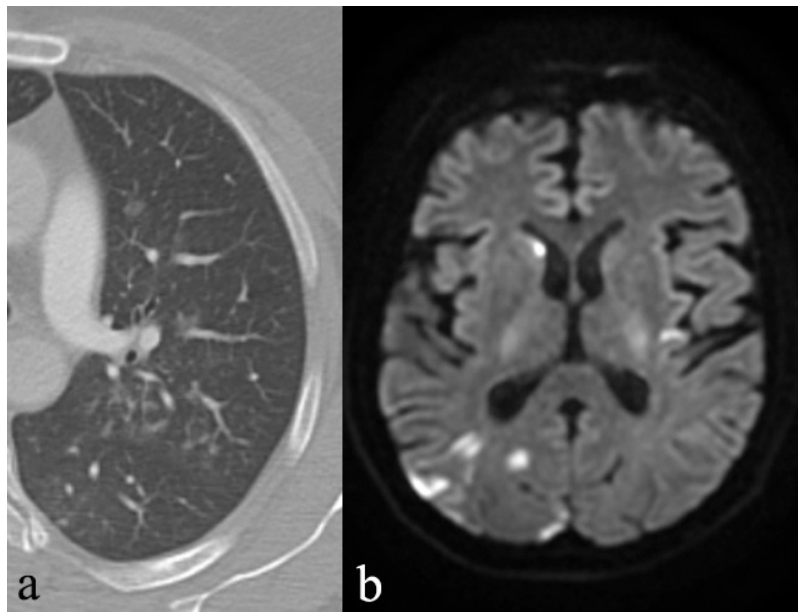

Figure 3 Focal ground-glass opacities in the left lung of COVID-19 infection (a), cranial diffusion MR image of the same patient (b) foci showing diffusion restriction from acute ischemic stroke

Presence of hypertension, history of coronary artery disease, diabetes mellitus type 2 , history of congestive heart failure as possible vascular risk factors obtained from medical records were questioned and recorded. A univariate analysis was performed to show the relationship of risk factors and the presence of COVID-19 with acute ischemic stroke.

\section{Statistical Analysis}

Patients with imaging findings consistent with acute ischemic stroke versus controls with imaging findings not compatible with acute ischemic stroke were compared according to age, gender, and major vascular risk factors. Pearson $\times 2$ test was used to compare categorical variables. Student $t$ test was performed for continuous variables. Statistical difference between acute ischemic stroke and control group was evaluated. All tests were 2-tailed and $p<0.05$ was considered statistically significant. While evaluating the findings obtained in the study, IBM SPSS Statistics 22 (IBM SPSS, Turkey) program was used for statistical analysis.

\section{RESULTS}

Patients presented with findings such as hemiplegia, unilateral sensory loss, dysarthria, facial asymmetry, aphasia, and acute mental status changes were evaluated as acute stroke suspicion. Because of this suspicion, 106 patients who underwent cranial diffusion MR imaging were included in the study. Acute stroke imaging findings were present in 39 of 106 patients included in the study. 67 patients without signs of acute ischemic stroke were considered as the control group. The mean age for subjects and controls was $61.8 \pm 4.8$ and $61.2 \pm 4.9$ years, respectively $(p<0.05)$. 
Seventeen (43.6\%) of the patients with acute ischemic stroke findings had COVID-19 infection. In the control group, 12 (17.9\%) were positive for COVID-19 ( $p<0.05$ ). While 23 (58.9\%) of the patients with acute ischemic stroke findings were male, $37(55.2 \%)$ of the control group were male $(p<0.05)$. There was no statistically significant difference between the ischemic stroke group and the control group for other risk factors such as type 2 diabetes mellitus, hypertension, coronary artery disease and heart failure (Table 1).

COVID-19 infection was found to be independently and significantly associated with patients with acute ischemic stroke compared to control subjects (OR $3.5 ; 95 \% \mathrm{Cl}$ $1.4-8.6 ; p<0.05)$.

\begin{tabular}{|c|c|c|c|c|}
\hline & $\begin{array}{l}\text { Group } 1 \\
\text { Acute } \\
\text { Ischemic } \\
\text { Stroke } \\
\text { Present }\end{array}$ & $\begin{array}{l}\text { Group } 2 \\
\text { Control } \\
\text { - No } \\
\text { ischemic } \\
\text { stroke }\end{array}$ & $p$ value & Total \\
\hline Number (n) & $39(\% 37)$ & $67(\% 63)$ & & 106 \\
\hline Age (years) & $61.8 \pm 4.8$ & $61.2 \pm 4.9$ & 0.521 & $61.4 \pm 4.9$ \\
\hline $\begin{array}{l}\text { Gender male } \\
\text { (n) }\end{array}$ & $23(\% 58.9)$ & $37(\% 55.2)$ & 0.710 & 60 \\
\hline COVID-19 (+) & $17(\% 43.6)$ & $12(\% 17.9)$ & 0.004 & 29 \\
\hline $\begin{array}{l}\text { Diabetes } \\
\text { Mellitus (+) }\end{array}$ & $12(\% 30.8)$ & $14(\% 20.9)$ & 0.255 & 26 \\
\hline $\begin{array}{l}\text { Hypertension } \\
(+)\end{array}$ & $16(\% 41)$ & 20 (\%29.9) & 0.241 & 36 \\
\hline $\begin{array}{l}\text { Coronary Heart } \\
\text { Dis. }(+)\end{array}$ & $9(\% 23.1)$ & $12(\% 17.9)$ & 0.520 & 21 \\
\hline Heart failure (+) & $9(\% 23.1)$ & $11(\% 16.4)$ & 0.398 & 20 \\
\hline
\end{tabular}

\section{DISCUSSION}

We evaluated the association of COVID-19 with traditional vascular risk factors with acute ischemic stroke as evidenced by imaging findings and found that COVID-19 is an independent risk factor for acute ischemic stroke. This finding supports that thromboembolic complications associated with COVID-19 infection are associated with increased morbidity and mortality.

It has been observed that underlying vascular problems are effective in the morbidity and mortality of many patients affected by COVID-19. In a meta-analysis of 6 studies published from China, it was reported that co-morbid conditions such as diabetes (9.7\%), cardiovascular disease (16.4\%), and hypertension (17.1\%) affect the prognosis of the disease in 1527 COVID-19 patients (19). In particular, patients with severe COVID-19 reported a three times higher incidence of cardiovascular disease than those with mild-to-moderate disease.

It is known respiratory tract infections increase the risk of acute ischemic stroke independent of COVID-19 infection (5-10). Grau et al. (7) reported that bacterial and viral infections are risk factors for the development of thromboembolism. In a study conducted in Wuhan, it was reported that 11 (5\%) of 221 COVID-19 patients developed acute ischemic stroke, and high C-reactive protein and D-dimer levels and increased coagulation tendency were mentioned in these patients (19).

In the report published by The International Society of Thrombosis and Haemostasis, fulminant activation of coagulation, depleting coagulation factors, was reported in patients with severe COVID-19 disease (20). Hypercoagulation and thromboembolic complications may be related to the severity of inflation and the extent of the disease. Different theories have been proposed regarding the mechanisms that increase the risk of ischemic stroke in systemic or respiratory tract infections. The most well-known ones are associated with changes in lipid metabolism and platelet aggregation, changes in endothelial function, and plaque instability and rupture $(21,22)$. It is known that in COVID-19 infection, SARS-CoV-2 virus attaches to cells via ACE 2 receptor, which is abundant in the vascular endothelium. It is thought that the cytokine storm that occurs after attachment to the receptors triggers hypercoagulation $(13,14)$. In addition, high D-dimer levels and platelet counts are often seen in severe cases of COVID-19. This may predispose patients to the development of acute ischemic stroke (23).

In this study, we wanted to evaluate the effect of COVID-19 on acute ischemic stroke, independent of other vascular risk factors, in patients within a certain age range. Our study shows that the incidence of acute ischemic stroke is significantly higher in patients with COVID-19 infection compared to those without infection. The presence of COVID-19 infection was associated with significantly more stroke cases than control subjects.

Our study has some limitations. First of all, as this was a retrospective study, there were some limitations in the clinical evaluation of the patients. In order to reduce the possible effects of age, cases between the ages of 40-70 were taken, demographic and some cardiovascular risk 
factors were included in the evaluation. However, risk factors as history of TIAs (transient ischemic attacks), smoking, hyperlipidemia, lack of exercise, excessive alcohol use and heredity and genetics for acute ischemic stroke could not be evaluated. Another limitation is our small sample size of 106 patients. In addition, the RT-PCR test, which can give false negative and false positive results, which can be considered a problem for all studies related to COVID-19, can be counted.

\section{CONCLUSION}

The incidence of thromboembolic complications is increased in COVID-19 patients, and the possible mechanism of these complications is the procoagulant pattern and endothelial thrombo-inflammatory syndrome, which may result in multisystemic thrombotic disease. Studies on the frequency of thromboembolic complications in COVID-19 patients, especially pulmonary embolism, are increasing; this study is showed an increased incidence of radiological imaging-proven acute ischemic stroke in COVID-19 patients. Future studies evaluating large populations together with the pathophysiological mechanisms present in COVID-19 will provide useful information. In addition, a wide evaluation of risk factors, organ and system-based evaluations in thromboembolic complications are needed. In conclusion, patients with COVID-19 should be carefully evaluated in terms of acute neurological changes and the possibility of acute ischemic stroke should not be overlooked and radiological imaging should not be delayed in order to reduce morbidity and mortality.

\section{DECLARATIONS}

Funding: None

Conflicts of interest/Competing interests: We have no conflict of interest to declare.

Ethics approval: HNEAH-KAEK-KK/2021/182

Availability of data and material: Not applicable

\section{Authors' contributions:}

Substantial contributions to the conception or design of the work; or the acquisition, analysis, or interpretation of data for the work; ANK, AV

Drafting the work or revising it critically for important intellectual content; AV, ANK
Final approval of the version to be published; ANK, AV

Agreement to be accountable for all aspects of the work in ensuring that questions related to the accuracy or integrity of any part of the work are appropriately investigated and resolved; ANK, AV

\section{REFERENCES}

1. Huang C, Wang Y, Li X, et al. Clinical features of patients infected with 2019 novel coronavirus in Wuhan, China. Lancet 2020;395:497-506. DOI: 10.1016/S0140-6736(20)30183-5

2. World Health Organization. Coronavirus disease 2019 (COVID-19) Situation report. https://covid19.who.int/. Accessed 23 March 2021.

3. Mahajan A, Hirsch JA. Novel coronavirus: what neuroradiologists as citizens of the world need to know. AJNR Am J Neuroradiol. 2020;41:552-54. DOI: 10.3174/ajnr.A6526

4. Jiang F, Deng $L$, Zhang $L$, et al. Review of the clinical characteristics of coronavirus disease. J Gen Intern Med. 2020;35:1545-49. DOI: 10.1007/s11606-020-05762-w

5. Zurrú MC, Alonzo C, Brescacín $L$, et al. Recent respiratory infection predicts atherothrombotic stroke: case-control study in a Buenos Aires healthcare system. Stroke 2009;40:1986-90. DOI: 10.1161/ STROKEAHA.108.535559

6. Grau AJ, Buggle F, Heindl S, et al.Recent infection as a risk factor for cerebrovascular ischemia. Stroke 1995;26:373-79.

7. Grau AJ, Buggle F, Becher $\mathrm{H}$, et al. Recent bacterial and viral infection is a risk factor for cerebrovascular ischemia: clinical and biochemical studies. Neurology 1998;50:196-203.

8. Bova IY, Bornstein NM, Korczyn AD.Acute infection as a risk factor for ischemic stroke. Stroke 1996;27:2204-06.

9. Clayton TC, ThompsonM, Meade TW. Recent respiratory infection and risk of cardiovascular disease: case-control study through a general practice database. Eur Heart J. 2008;29:96-103. DOI: 10.1093/eurheartj/ehm516

10. Mao L, Jin H, Wang M, et al. Neurologic Manifestations of Hospitalized Patients with Coronavirus Disease 2019 in Wuhan, China. JAMA Neurol. 2020;77(6), 683-690. DOI: 10.1001/jamaneurol.2020.1127

11. Zhou F, Yu T, Du R, et al. Clinical course and risk factors for mortality of adult inpatients with COVID-19 in Wuhan, China: a retrospective cohort study. Lancet 2020;395:1054-62. DOI: 10.1016/ S0140-6736(20)30566-3

12. Hamming I, Timens $W$, Bulthuis $M$ et al. Tissue distribution of ACE2 protein, the functional receptor for SARS coronavirus: a first step in understanding SARS pathogenesis. J Pathol. 2004;203:631-637. DOI: 10.1002/path.1570

13. Mehta P, McAuley DF, Brown M, et al. COVID-19: consider cytokine storm syndromes and immunosuppression. Lancet 2020;395:10334. DOI: 10.1016/S0140-6736(20)30628-0

14. Connors JM, Levy JH.COVID-19 and its implications for thrombosis and anticoagulation. Blood 2020;135(23):2033-40. DOI: 10.1182/ blood.2020006000

15. Algahtani H, Subahi A, Shirah B. Neurological complications of Middle East respiratory syndrome coronavirus: a report of two cases and review of the literature. Case Rep Neurol Med. 2016;1:6. DOI:10.1155/2016/3502683

16. Chen N, Zhou M, Dong $X$ et al. Epidemiological and clinical characteristics of 99 cases of 2019 novel coronavirus pneumonia in Wuhan, China: a descriptive study. Lancet 2020;395:507-13. DOI: 10.1016/S0140-6736(20)30211-7 
17. Han $\mathrm{H}$, Yang L, Liu R, et al. Prominent changes in blood coagulation of patients with SARS-CoV-2 infection. Clin Chem Lab Med. 2020;58(7):1116-20. DOI: 10.1515/cclm-2020-0188

18. Belani P, Schefflein J, Kihira S, et al. COVID-19 Is an Independent Risk Factor for Acute Ischemic Stroke. AJNR Am J Neuroradiol. 2020;41(8):1361-4. DOI: 10.3174/ajnr.A6650

19. Li B, Yang J, Zhao F, et al. Prevalence and impact of cardiovascular metabolic diseases on COVID-19 in China. Clin Res Cardiol. 2020;109:531-38. DOI: 10.1007/s00392-020-01626-9

20. Kaur $P$, Qaqa $F$, Ramahi $A$, et al. Acute upper limb ischemia in a patient with COVID-19. Hematol Oncol Stem Cell Ther 2020. [Epub ahead of print] DOI: 10.1016/j.hemonc.2020.05.001

21. Ameriso SF, Wong VL, Quismorio FP, et al. Immunohematologic characteristics of infection-associated cerebral infarction. Stroke 1991;22:1004-09.

22. Mittleman MA, Mostofsky E. Physical, psychological and chemical triggers of acute cardiovascular events: preventive strategies. Circulation 2011;124:346-54. doi: 10.1161/ CIRCULATIONAHA.110.968776

23. Wu Y, Xu X, Chen Z, et al. Nervous system involvement after infection with COVID-19 and other coronaviruses. Brain Behav Immun. 2020;87:18-22. DOI: 10.1016/j.bbi.2020.03.031 